City University of New York (CUNY)

CUNY Academic Works

\title{
A Preliminary Investigation of Technical Services Librarians' Contributions to Library Guides in Academic Libraries
}

Junli Diao

CUNY York College

\section{How does access to this work benefit you? Let us know!}

More information about this work at: https://academicworks.cuny.edu/yc_pubs/284

Discover additional works at: https://academicworks.cuny.edu

This work is made publicly available by the City University of New York (CUNY).

Contact: AcademicWorks@cuny.edu 
This is a preprint of an article whose final and definitive form was published in Technical Services Quarterly 38(3), 236-257. Print ISSN: 0731-7131 Online ISSN: 1555-3337. Online published on May 16, 2021. The final authenticated version is available at: https://doi.org/10.1007/s11192-021-040186. Copyright 2021. Taylor \& Francis.

\section{A Preliminary Investigation of Technical Services Librarians' Contributions to Library Guides in Academic Libraries}

\section{Junli Diao}

Junli Diao

Assistant Professor/Head of Cataloging and Serials York College Library of the City University of New York

Email:jdiao@york.cuny.edu

Office: 718-262-2302 
This is a preprint of an article whose final and definitive form was published in Technical Services Quarterly 38(3), 236-257. Print ISSN: 0731-7131 Online ISSN: 1555-3337. Online published on May 16, 2021. The final authenticated version is available at: https://doi.org/10.1007/s11192-021-040186. Copyright 2021. Taylor \& Francis.

\title{
A Preliminary Investigation of Technical Service Librarians' Contributions to Library Guides in Academic Libraries
}

\begin{abstract}
Online library guides are one of the bridges that librarians build to connect users to available resources and services. Since the time when library guides were conceived in the pamphlets and book lists of the early days, a historical brand bearing public and instructional services librarians' merit and reputation has been watermarked in their presentation. In the internet age, have technical services librarians also played a role in contributing to library guides in academic libraries to assist students' learning and faculty teaching? If so, do technical services librarians who are working as faculty tend to produce more library guides than ones as professionals? Do librarians working in six functional areas, namely, Acquisition, Cataloging \&Metadata, Collection Development, Continuing \& Electronic Resources, Preservation, and Technical Services (Solo) have similar contributions to library guides? What types of library guides do they tend to produce more? Any recommendations for future library guide work which technical services librarians will engage in? This research examined 233 colleges and universities and examined 296 academic libraries, attempting to find answers to these questions.
\end{abstract}

Keywords: library guide, subject guide, course guide, technical services librarian, librarian as faculty, librarian as professional 
This is a preprint of an article whose final and definitive form was published in Technical Services Quarterly 38(3), 236-257. Print ISSN: 0731-7131 Online ISSN: 1555-3337. Online published on May 16, 2021. The final authenticated version is available at: https://doi.org/10.1007/s11192-021-040186. Copyright 2021. Taylor \& Francis.

\section{A Preliminary Investigation of Technical Service Librarians' Contributions to Library Guides in Academic Libraries}

\section{Introduction}

If a library could be compared to a boat, then public services would be the flag and technical services the propeller. The flag stands tall and highlights the boat's visibility, lending itself to being a conspicuous reminder of its status and functions. However, the propeller stays below and hidden, spinning silently and repeatedly and keeping the boat going forward at a steady speed. Technical services and public services are traditionally seen as two dichotomous, divided functional areas in a library. Librarians in each area fulfill their conjured duties with respect of the invisible but distinctive boundary in between them. Although chances are very small, but still possible, public services librarians find themselves to be in a situation where they are expected to undertake some technical services responsibilities (Fain \& Faix, 2004). However, instead of working behind the scenes all day long, technical services librarians may more often than not have to step out of the so-called back rooms and perform emerging duties in public and instructional services (Barrette, 2011; Diao, 2020; Folsom, 2000; Hristov, 2005; Leverence, 1996; McCallum \& Collins, 2011; Turner \& Nann, 2013).

Although the above literature published in the Library and Information Science has already well documented the instances of how technical services librarians reengineered their stereotyped images by expanding their roles at the reference desk or in the information literacy classroom, there is one field in the library left substantially unexplored. This field is online library guides. Current literature on library guides focuses on the evolution, implementation, design, best practices, assessment and evaluation, pedagogical significance. There is no existing empirical research that explores the connection between library guides and library functional areas, such as technical services. Ghaphery and Whit (2012) offered a detailed portrayal of the characteristics of library guides from 99 members of the American Research Libraries (ARL). At the end, the researchers left a few unanswered questions, which include "How do attitudes toward research guides differ between public services and technical services? (p. 28). Almost one decade has passed; however, this question still remains unanswered in the literature. Perhaps, it is not easy to survey the attitude differences between public services and technical services librarians regarding library guides. The attitude survey could possibly involve arguments on personal beliefs and value judgments, which might lead to the setup of an unnecessary contrast between these two cohorts since public services and technical services librarians have different philosophies of serving customers. It might be a better idea to research what has been done out 
This is a preprint of an article whose final and definitive form was published in Technical Services Quarterly 38(3), 236-257. Print ISSN: 0731-7131 Online ISSN: 1555-3337. Online published on May 16, 2021. The final authenticated version is available at: https://doi.org/10.1007/s11192-021-040186. Copyright 2021. Taylor \& Francis.

there, instead of probing "What do you think of it?" in their minds. Therefore, this study will focus on the results, which means library guides currently available on the website of academic libraries. Specifically speaking, this study will explore whether technical service librarians have played a role in creating library guides in academic libraries and, if so, to what extent.

\section{Literature Review}

\section{History of Library Guides}

The concept of current library guides demonstrates an intimate link to the early days of modern library movement. According to Smith (2008), the forerunners of library guides can be traced from pamphlets of private collections developed by scholars in American universities at the end of 19th century. In the 1950s, booklists and recommended readings created by bibliographers for a specific topic or subject emerged in the library and received popularity among readers. In the $1960 \mathrm{~s}$, booklists were brought into library instruction to facilitate teaching; hence, the term pathfinder emerged from Patricia Knapp and Monteith College faculty's collaborative pedagogical experiment that encouraged students to find a path leading to the library's resources on their own. In the 1970s, pathfinders were formalized as "short, one-page instructional guides on researching a narrow, specific subject" (p. 515) by librarian Charles Stevens and Marie Canfield in the Model Library Project at the Massachusetts Institute of Technology. Since then, the paper-based, brochure-like pathfinders, which catered to prominent resources of a particular discipline available in libraries, earned their places at the reference and instructional services as an attested, useful tool until the rise of internet.

The use of the internet gave birth to the second-generation library guides called "borndigital," "home-grown" guides (Giullian \& Zitser, 2015, p. 172). The second generation library guides were developed by individual libraries and hosted on their websites. They were mostly free and open-accessed; however, creating such a library guide required that librarians have a good knowledge of programming, such as HTML and CSS. Therefore, designing and managing library guides turned out to be an exciting adventure, but a labor-intensive and time-consuming project. Regardless of the technology challenges, each librarian programmed their own library guides, which resulted in duplicated effort and inconsistent formatting. Empowered by thirdparty, commercial platform providers, the third-generation library guides overcome those challenges. They "allow librarians to leave behind the technological side of online guides and to focus on finding, creating, and uploading their content" (Giullian \& Zitser, p. 173). The popular platform that dominates the current library's landscape is called LibGuides, a product of Springshare founded in 2007 by Slaven Zivkovic, "an ed-tech entrepreneur with a history of library innovations" (Springshare, 2021). With the integration of Web 2.0 technology and a userfriendly interface, LibGuides can be flexibly customized into a library's website and require little

programming knowledge from librarians, nor system support from libraries. All these advantages 
This is a preprint of an article whose final and definitive form was published in Technical Services Quarterly 38(3), 236-257. Print ISSN: 0731-7131 Online ISSN: 1555-3337. Online published on May 16, 2021. The final authenticated version is available at: https://doi.org/10.1007/s11192-021-040186. Copyright 2021. Taylor \& Francis.

make LibGuides a globally popular platform for libraries' content management. As of now, LibGuides have been used by over 6,100 libraries located in 82 countries and over 130,000 librarians have participated in creating library guides.

\section{Technical Services and Library Guides}

Library guides, either their forerunner pamphlets designed by scholars one hundred years ago, or current ones that librarians created in a third-party content management system, are essentially reference or pedagogical instruments that assist users in stepping into introductory, subject-specific resources available in libraries. As for technical services librarians' contribution to library guides, the existing literature only demonstrates experience-sharing anecdotes that technical service librarians took advantage of library guides for the purpose of professional development: documenting departmental activities, policies, and projects, or increasing crossdepartmental communication and collaboration within libraries.

Bazeley and Yoose (2012)'s case study evidenced that Libguides was used as a solution to address "a persistent problem faced by technical services departments: documenting and conveying important information to staff outside of the department" (p. 127). The library guide they created was proven to be an effective tool to publicize information to other departments regarding staff contact, collection analysis, wedding and gifts policy, ebooks, serials and databases, e-resource usage, and open access. Baker and Mortimore (2016) shared their experience of how technical and instructional services librarians collaborated together to face pedagogical challenges through creating library guides related to a variety of library resources. Cannon-Rech and Mortimore (2020) highlighted a collaborative Open Educational Resources (OER) project between liaison and technical services librarians and faculty. Technical services librarians creatively took advantage of LibGuides as a platform to host OER materials and provided assistance in transforming one-shot instructional model so as to meet the emerging and evolving needs of content management from faculty. As is shown from the reviewed literature above, there is no systematic, empirical study that specifically outlines technical service librarians' overall contribution to library guides, except for a few sporadic cases that provided a report of best practices in creating library guides to fulfill technical services departmental goals or creative implementations to support faculty's pedagogical needs. In addition, most of the existing large-scale studies on the investigation of library guides preferred to extract samples from ARL member libraries (Anderson \& Springs, 2016; Ghaphery \& White, 2012; Jackon \& Pellack, 2004; Linares \& Johnson, 2016). This preference left out a large portion of academic libraries that are not members of ARL. Hence, continued effort is expected to expand the research to a broader scope that includes college and university libraries that were neglected.

\section{Methods}


This is a preprint of an article whose final and definitive form was published in Technical Services Quarterly 38(3), 236-257. Print ISSN: 0731-7131 Online ISSN: 1555-3337. Online published on May 16, 2021. The final authenticated version is available at: https://doi.org/10.1007/s11192-021-040186. Copyright 2021. Taylor \& Francis.

\section{Identifying Academic Libraries}

This study aimed to research technical services librarians' contribution to library guides in academic libraries. To identify academic libraries to be used as samples in this study, the researcher took advantage of a list of academic institutions grouped into four categories by librarians' statuses: librarians with full faculty status and tenure, librarians with faculty status but no tenure, librarians with a mix of statuses, librarians without faculty status, and librarians without faculty status but with a status similar to tenure. This list was originally compiled by Chris Lewis at American University and is available online at https://academiclibrarianstatus.wordpress.com/2018/03/22/academic-librarian-status/. The researcher accessed this list on January 1, 2021 and reorganized this list into two broader groups: libraries that treat librarians as faculty and libraries that consider librarians as professionals. Libraries, which offer librarians mixed statuses in the original list, were excluded in this study so as to avoid an intrusive inquiring of individual technical service librarian's specific job title status.

A college or a university could have multiple libraries, possibly with affiliated libraries. If all the library guides are aggregated in a centralized webpage, this study counted it as one college/university and one library. A typical example is New York University (NYU). NYU has multiple libraries and affiliated libraries. Its library guides are grouped all together in the main library's web site. If a university system has multiple campus libraries that manage library guides individually, this study counted it as one university and multiple libraries. For instance, California State University is comprised of 22 campus libraries with independent library guides, and it was counted as one university and 22 libraries. Libraries that restricted library guides' access were excluded from this study. Built on the original list compiled by Lewis (2018), this study identified 246 libraries coming from 192 colleges and universities that treat librarians as faculty, abbreviated as the Libraries (Faculty) hereafter (See Appendix A), and 50 libraries from 41 colleges and universities that consider librarians as professionals, shortened as the Libraries (Professional) (See Appendix B).

\section{Definition of Technical Services}

Based on the Online Dictionary for Library and Information Science, technical services are defined as "library operations concerned with the acquisition, organization, physical processing, and maintenance of library collections, as opposed to the delivery of public services." The American Library Association (2021) provides a list of functional areas that a technical services librarian could work in. These functional areas include acquisition, collection development and management, cataloging, classification, continuing resources, and preservation and archives. Although special collections librarians and archivists also undertake the responsibilities of acquiring, organizing, and processing materials, they are not considered 
This is a preprint of an article whose final and definitive form was published in Technical Services Quarterly 38(3), 236-257. Print ISSN: 0731-7131 Online ISSN: 1555-3337. Online published on May 16, 2021. The final authenticated version is available at: https://doi.org/10.1007/s11192-021-040186. Copyright 2021. Taylor \& Francis.

technical services professionals. The former position requires a variety of competences, including public and instructional services, and the latter demands a different degree or professional training. Based on the job titles collected and analyzed, this study investigated six functional areas, which are Acquisition, Cataloging \& Metadata, Collection Development, Continuing \& Electronic Resources, Preservation, and Technical Services (Solo). Technical Services (Solo) refers to the position that expects one librarian to undertake the responsibilities of multiple/all functional areas. In addition, this study included Technical Services (General) as an umbrella area to cover the characteristics of six functional categories in the Libraries (Faculty) and the Libraries (Professional).

\section{Research Question and Hypotheses}

This study attempted to investigate whether technical services librarians play a role in creating library guides in two categories of academic libraries: the Libraries (Faculty) and the Libraries (Professional). This study sought to answer one research question and test seven hypotheses in Acquisition, Cataloging \& Metadata, Collection Development, Continuing \& Electronic Resources, Preservation, Technical Services (Solo), and Technical Services (General).

1. What is the status quo of library guides created by technical services librarians in academic libraries?

2. To reduce redundancy, seven hypotheses are summarized together as: no significant difference between the proportions of library guides created by Acquisition, Cataloging \& Metadata, Collection Development, Continuing \& Electronic Resources, Preservation, Technical Services (Solo), and Technical Services (General) in the Libraries (Faculty) and in the Libraries (Professional). Alternative hypotheses are: library guides created by Acquisition, Cataloging \& Metadata, Collection Development, Continuing \& Electronic Resources, Preservation, Technical Services (Solo), and Technical Services (General) in the Libraries (Faculty) are proportionately greater than the counterparts in the Libraries (Professional).

\section{Data Collection and Analysis}

All the data regarding library guides in this study were accessed, collected, and analyzed between January 7 and February 1, 2021. The researcher first accessed the homepages of individual libraries and located their library guides. Then the researcher identified who technical services librarians were in that library through accessing employees' profiles. Next the researcher compared employee's profile information and library guides owners' information so as to determine whether they were the same librarians. The total number of library guides in individual libraries, the job titles of specific technical services librarians, the number of library 
This is a preprint of an article whose final and definitive form was published in Technical Services Quarterly 38(3), 236-257. Print ISSN: 0731-7131 Online ISSN: 1555-3337. Online published on May 16, 2021. The final authenticated version is available at: https://doi.org/10.1007/s11192-021-040186. Copyright 2021. Taylor \& Francis.

guides under associated names, and types of library guides, numbers of library guides associated with each type were coded in Microsoft Excel spreadsheets.

If one librarian's job title is made up of two or more components, data was coded by the first, which was considered as the main responsibility. For instance, library guides created by an Acquisitions and Resource Management Librarian was entered under Acquisition and guides developed by Metadata and Collection Development Coordinator under Cataloging \& Metadata. Subject librarians may undertake the responsibility of collection development, too; however, their library guides were counted in this study only when their names and titles appeared in the collection department. If they were administrated by the department of instruction, research or public services, their library guides were not counted as contributions made by Collection Development. Compared with other functional areas, Continuing \& Electronic Resources is a broader category that covers more titles, including Serials Librarian, Periodical Librarian, Electronic Resources Librarian, Electronic Resources and Serials Librarians, Electronic Collection Coordinator, etc.

In terms of the types of library guides, Springshare offers a variety of default options for librarians to choose or for the administrators to customize. Subject guides and/ course guides have a much higher appearance than the rest. Therefore, this study grouped all the guides into three categories: subject guides, course guides, and others. Others include topic guides, general guides, how-to guides, and a few variations customized as guides by resources, tutorials and services, etc. If library guides are only alphabetically listed on the webpage without defining their types, then the researcher checked each library guide to see whether it carried a distinctive subject or a course code. If it had a subject feature, it was counted as a subject guide; if a guide contained a course code, it was treated as a course guide; the rest was grouped as others. If the auto-display of guides' numbers was inactivated, the researcher copied and pasted all library guides into a separate spreadsheet and did the calculation there. It was rare, but still happened, that library guides on the main webpage did not display their owners' names. The researcher utilized Search within Guides function by searching librarians' full names, identified their profiles, and located associated library guides. In addition, only three libraries used SubjectPlus as a platform to host their library guides and the rest all favored Springshare. Library guides developed by SubjectPlus were also taken into consideration for analysis.

\section{Results}

Due to the pandemic, the researcher was not able to get access to SPSS in the office. Therefore, both descriptive analysis and z-test significance calculation were done by using mathcracker, which is a free online statistical tool and available at https://mathcracker.com/.

\section{Descriptive Analysis}


This is a preprint of an article whose final and definitive form was published in Technical Services Quarterly 38(3), 236-257. Print ISSN: 0731-7131 Online ISSN: 1555-3337. Online published on May 16, 2021. The final authenticated version is available at: https://doi.org/10.1007/s11192-021-040186. Copyright 2021. Taylor \& Francis.

This study examined 233 colleges and universities and covered 296 libraries. As is shown in Table 1, 192 colleges and universities with 246 libraries, which treat librarians as faculty, produced a total number of 47,602 library guides. The average number of guides per library is 193.50, with the lowest 3 and the highest 1,496. As for libraries that considered librarians as professionals, 50 libraries from 41 colleges and universities generated a total number of 16,265 library guides, with 325.3 guides as the average number per library, 29 the lowest, and 930 the highest. Overall, Technical Services (General) in the Libraries (Faculty) produced 2,716 library guides and that in the Libraries (Professional) created 1,240 library guides. This provides an answer to the first research question that Technical Services (General) does play a role in creating library guides in academic libraries.

\section{[place Table 1 here]}

In the Libraries (Faculty), Table 2 shows that, out of 47,602 library guides, 2,716 $(5.71 \%)$ library guides generated by Technical Services (General), which include 1,070 (2.25\%) subject guides, $646(1.36 \%)$ course guides, and 1,000 (2.10\%) others. In terms of individual functional areas, Collection Development contributed 1,005 (2.11\%) library guides (355 subject guides; 300 course guides; 350 others), Continuing \& Electronic Resources 759 (1.59\%) library guides (274 subject guides; 154 course guides; 331 others), Cataloging \& Metadata 509 (1.07\%) library guides (218 subject guides; 132 course guides; 159 others), Technical Services (Solo) 277 $(0.58 \%)$ library guides (150 subject guides; 26 course guides; 101 others), Acquisition 159 $(0.33 \%)$ library guides (68 subject guides; 34 course guides; 57 others), and Preservation 7 ( $0.01 \%$ ) library guides ( 5 subject guides; 0 course guides; 2 others).

\section{[place Table 2 here]}

Table 3 shows that, out of the total number of 16,265 library guides, Technical Services (General) in the Libraries (Professional) created 1,240 (7.62\%) library guides, which constitute $581(3.57 \%)$ subject guides, 299 (1.84\%) course guides, and $360(2.21 \%)$ others. Further, 1,066 (6.55\%) library guides (523 subject guides, 272 course guides, and 271 others) come from Collection Development, 79 library guides (0.49\%) (24 subject guides, 3 course guides, and 52 others) from Continuing \& Electronic Resources, 52 library guides (0.32\%) (22 subject guides, 15 course guides, and 15 others) from Acquisition, 34 (0.21\%) library guides (8 subject guides, 9 course guides, and 17 others) from Cataloging \& Metadata, $9(0.06 \%)$ library guides (4 subject guides and 5 others) from Technical Services (Solo), and no contribution of library guides evidenced from Preservation.

[place Table 3 here]

\section{Z-test Significance Calculation}


This is a preprint of an article whose final and definitive form was published in Technical Services Quarterly 38(3), 236-257. Print ISSN: 0731-7131 Online ISSN: 1555-3337. Online published on May 16, 2021. The final authenticated version is available at: https://doi.org/10.1007/s11192-021-040186. Copyright 2021. Taylor \& Francis.

A z-test for the significance of proportions of library guides contributed by six functional areas and Technical Services (General) in two total numbers $(47,602$ and 16,265) was conducted to test seven hypotheses (See Table 4). Due to the proportion numbers of Preservation in the Libraries (Professional) is $0, \mathrm{H}_{5}$ was not taken into consideration for further analysis. The results of $\mathrm{H}_{1}, \mathrm{H}_{3}$, and $\mathrm{H}_{7}$ were not statistically significant $(\mathrm{z}=0.28,-27.62$, and -8.76 sequentially; $\mathrm{p}>$ 0.05 , one-tailed). That means that these three null hypotheses were accepted, which leads to the conclusion that the proportions of library guides contributed by Acquisition, Collection Development, and Technical Services (General) in the Libraries (Faculty) were not statistically greater than corresponding areas in the Libraries (Professional). The results of $\mathrm{H}_{2}, \mathrm{H}_{4}$ and $\mathrm{H}_{6}$ were statistically significant $(\mathrm{z}=10.32,10.73$, and 8.68 sequentially; $\mathrm{p}<0.05$, one-tailed $)$. The results indicate that those three null hypotheses were rejected. It is concluded that the proportions of library guides contributed by Cataloging \& Metadata, Continuing \& Electronic Resources, and Technical Services (Solo) in the Libraries (Faculty) were statistically greater than corresponding areas in the Libraries (Professional).

[place Table 4 here]

\section{Findings}

The legacy that public and instructional services librarians inherited from creating pamphlets and pathfinders before internet put a historical trademark of their effort in current library guides in academic libraries. However, this study reveals that technical services librarians also played a significant role in creating library guides. Findings of this study can be summarized as below.

Generally speaking, technical services librarians from both library cohorts unequally engaged in creating library guides. 2,716 (5.71\%) library guides in the Libraries (Faculty) and 1,240 (7.62\%) library guides in the Libraries (Professional) were associated with technical services librarians. However, unequal contribution is not statistically supporting the argument that Technical Services (General) in the Libraries (Faculty) tend to produce more library guides than that in the Libraries (Professionals) proportionally. In other words, it is very safe to say that librarians as faculty cannot be considered as an impetus that encourages technical services librarians to have more participation in library guides. Nor does it necessarily mean that technical services librarians who are working in a non-faculty position will have less engagement in creating library guides than those who are working in a faculty position. Statistical analysis demonstrates this claim is also relevant to two other functional areas: Acquisition and Collection Development. If librarians' status as faculty could be positively correlated with technical services librarians' participation in creating library guides, this claim is only statistically evidenced in three functional areas: Cataloging \& Metadata, Continuing \& Electronic Resources, and Technical Services (Solo). 
This is a preprint of an article whose final and definitive form was published in Technical Services Quarterly 38(3), 236-257. Print ISSN: 0731-7131 Online ISSN: 1555-3337. Online published on May 16, 2021. The final authenticated version is available at: https://doi.org/10.1007/s11192-021-040186. Copyright 2021. Taylor \& Francis.

Specifically speaking, this study revealed a few interesting findings. First, Collection Development has the most proportion of library guides and Preservation has the least in both the Libraries (Faculty) and the Libraries (Professional). Collection development librarians are mainly responsible for selecting and maintaining library materials relevant and useful for students and faculty. Compared with other librarians, they are in a much better position to tell users what resources a library has and what resources a library doesn't (Patel, 2016). Therefore, for collection development librarians, creating library guides seems to be a natural task that opens up an avenue for recommending subject-related and/or course-related resources so as to meet the demand of users and curriculum. The small contribution from Preservation could be caused by several reasons. This study only collected data from preservation librarians who deal with physical materials; data from digital preservation librarians were not included. During the process of data collection, the researcher also observed that, in most cases, it was paraprofessional titles relating to preservation, such as assistants, specialists, or associates, were listed in their profiles, instead of formal librarians' titles. This is also a sign that preservation librarians are suffering deprefessionalization in academic libraries. This phenomenon was subtly implied in the literature (Durant \& Smith, 2019; Miller \& Horan, 2017).

Second, regarding the types of library guides, the researcher observed a general trend that, either in Technical Services (General) or in almost six individual functional areas in both the Libraries (Faculty) and the Libraries (Professional), more subject guides were produced than course guides. Working in academic libraries requires librarians possess at least two Masters' degrees: one in the Library and Information Science and one in a subject discipline. Accordingly, creating library guides relating to their subject knowledge become an important on-call responsibility. Subject guides are proven resource tools not only useful for students and faculty, but also convenient orientation instruments for new librarians or liaison librarians assigned a new area to gain instant knowledge of subject resources (Bagshaw \& Yorke-Barber, 2018). Regardless of their popularity, subject guides run the risk of becoming laundry lists of librarianassumed best resources. Therefore, Dalton and Pan (2014) recommended that librarians, who are designing subject guides, should try to collaborate with faculty and students, because subject guides with a broad content have little meaning to them. Participation from faculty and students will lead to the inclusion of information tailored to their specific needs and help reduce information overload. Reeb and Gibbons (2014) pointed out that librarians should create more course-level guides for undergraduate students because their mindset gives importance to coursework rather than subject discipline. The other way around is that subject guides best fits graduate students who are in pursuit of a deeper understanding of discipline knowledge. Findings in this study, plus arguments in the literature, is something that technical services librarians need to balance in their minds when it comes time to create library guides to serve faculty and students. 
This is a preprint of an article whose final and definitive form was published in Technical Services Quarterly 38(3), 236-257. Print ISSN: 0731-7131 Online ISSN: 1555-3337. Online published on May 16, 2021. The final authenticated version is available at: https://doi.org/10.1007/s11192-021-040186. Copyright 2021. Taylor \& Francis.

\section{Limitations and Further Research}

Limitations of this study are apparent, too. First, it is the potential imperfection of the source of information that the researcher used to categorize academic libraries. With a comprehensive coverage of colleges and universities in the United States and Canada, the original list laying a foundation for this study is in the process of revision and updating. It could contain inaccurate information. However, it is still the only available source that the researcher was able to find within his capacity. Second, this study is considered as a preliminary research focusing on technical services librarians' contribution to library guides. It calls for continued effort to further explore this topic in full detail. For instance, the others, categorized as a type of library guides, have a comprehensive coverage. It not only includes how-to guides, topic guides, but also covers the guides that technical services librarians created for other purposes. Perhaps, a future study, which focuses on the topic of how technical services librarians in academic libraries utilize library guides for non-academic purposes, would be a good idea to pursue. In addition, a few reasonable questions stemming out of data collection process also merit further attention. For example, do technical services librarians tend to be assigned to serve as subject liaisons? Do technical services librarians who undertake subject liaison work tend to contribute more subject guides and/or course guides in comparison with ones who don't involve in subject liaison work? When questions as such have been answered, a full, comprehensive image of technical services librarians' contribution to library guides will be eventually revealed.

\section{Conclusion}

This study aimed to provide a better understanding of technical services librarians' contribution to library guides in academic libraries. This study also wanted to test whether their engagement in library guides is intimately associated with their status as faculty or as professionals. Findings indicate that technical services librarians have played a role in creating library guides to facilitate their users to find useful information relating to subjects and courses in academic libraries. However, the findings do not support the argument that this role is overall positively tied to their faculty status, except in Cataloging \& Metadata, Continuing \& Electronic Resources, and Technical Services (Solo). Findings also state that, overall, technical services librarians in academic libraries produced more subject guides than course guides.

In the past decade, technical services librarians attempted to reassess their roles and rearticulate the definition of services when academic libraries were facing the challenges imposed by budget cuts, organizational restructuring, and technological advancement. The voice of Technical services is public services is appearing in journal articles, conference events, and social media (Barrette, 2011; Eustis, 2012; Fisher, 2003; Hiatt, 2015; Mlinar, 2014). However, without active and deep participation in the areas where public and instructional librarians built a tradition in the past and hold a reputation of mastery at present, Technical services is public 
This is a preprint of an article whose final and definitive form was published in Technical Services Quarterly 38(3), 236-257. Print ISSN: 0731-7131 Online ISSN: 1555-3337. Online published on May 16, 2021. The final authenticated version is available at: https://doi.org/10.1007/s11192-021-040186. Copyright 2021. Taylor \& Francis.

services could fall into a trap of empty dispute or end with a game of words. Technical services librarians, either as faculty or professionals, should free themselves from the yoke of backroom mentality and step into the areas that call for individual librarian's knowledge and expertise for the best interest of users. In this sense, there is more work left to be done in library guides. "The most effective way to do it, is to just do it." (Amelia Earhart) 
This is a preprint of an article whose final and definitive form was published in Technical Services Quarterly 38(3), 236-257. Print ISSN: 0731-7131 Online ISSN: 1555-3337. Online published on May 16, 2021. The final authenticated version is available at: https://doi.org/10.1007/s11192-021-040186. Copyright 2021. Taylor \& Francis.

\section{References}

Anderson, K. E., \& Springs, G. R. (2016). Assessing librarian expectations before and after LibGuides implementation. Practical Academic Librarianship: The International Journal of the SLA Academic Division, 6(1), 19-38. http://hdl.handle.net/1811/77869

Bagshaw, A., \& Yorke-Barber, P. (2018). Guiding librarians: Rethinking library guides as a staff development tool. Journal of the Australian Library and Information Association, 67(1), 31-41. https://doi.org/10.1080/24750158.2017.1410629

Baker, R., \& Mortimore, J. M. (2016). Guides by the side: The role of technical services in information literacy instruction. Retrieved from https://digitalcommons.georgiasouthern.edu/gaintlit/2016/2016/1/

Barrette, L. (2011). Technical services is public service: Or how I got out of the back room and why you should too. Retrieved from https://commons.law.famu.edu/library-facpub/2/

Bazeley, J. W., \& Yoose, B. (2013). Technical services transparency: Using a LibGuide to expose the mysteries of technical services. Library Resources \& Technical Services, 57(2), 118-127. http://hdl.handle.net/11084/324

Dalton, M., \& Pan, R. (2014). Snakes or ladders? Evaluating a LibGuides pilot at UCD Library. The Journal of Academic Librarianship, 40(5), 515-520. https://doi.org/10.1016/j.acalib.2014.05.006

Diao, J. (2020). The concept, design, implementation, and assessment of Case-Based Learning in an information literacy classroom. International Journal of Librarianship, 5(1), 108-127. https://doi.org/10.23974/ijol.2020.vol5.1.156.

Durant, F., \& Smith, B. (2019). Preservation Librarian: Position overview. In M. Hodge (Ed.), The Future Academic Librarian's Toolkit: Finding Success on the Job Hunt and in Your First Job (pp. 182-189). American Library Association.

Eustis, J. (2012). Cataloging is a public service. Retrieved from https://celeripedean.wordpress.com/2012/03/15/cataloging-is-a-public-service/

Fain, M., Brown, M., \& Faix, A. (2004). Cross-training reference librarians to catalog. Technical Services Quarterly, 22(1), 41-53. https://doi.org/10.1300/J124v22n01_0

Fisher, W. (2003). The Electronic Resources Librarian position: A public services phenomenon? Library Collections, Acquisitions, and Technical Services, 27(1), 3-17. https://doi.org/10.1016/S1464-9055(02)00303-2

Folsom, S. L. (2000). Out of the nest: The cataloger in a public services role. Library Collections, Acquisitions, and Technical Services, 24(1), 65-71. https://doi.org/10.1016/S14649055(99)00098-6

Ghaphery, J., \& White, E. (2012). Library use of web-based research guides. Information Technology and Libraries, 31(1), 1-11. https://doi.org/10.6017/ital.v31i1.1830

Giullian, J. C., \& Zitser, E. A. (2015). Beyond LibGuides: The past, present, and future of online research guides. Slavic \& East European Information Resources, 16(4), 170-180. https://doi.org/10.1080/15228886.2015.1094718 
This is a preprint of an article whose final and definitive form was published in Technical Services Quarterly 38(3), 236-257. Print ISSN: 0731-7131 Online ISSN: 1555-3337. Online published on May 16, 2021. The final authenticated version is available at: https://doi.org/10.1007/s11192-021-040186. Copyright 2021. Taylor \& Francis.

Hiatt, C. D. (2015). Technical services is public services. Technicalities, 35(5), 8-10. http://hdl.handle.net/10339/57380.

Hristov, M. N. (2005). Trends, issues and practical solutions for cross training catalogers to provide reference services: A survey-based study. Technical Services Quarterly, 23(1), 35-51. https://doi.org/10.1300/J124v23n01_04

Jackson, R., \& Pellack, L. J. (2004). Internet subject guides in academic libraries: An analysis of contents, practices, and opinions. Reference \& User Services Quarterly, 43(4), 319-327. https://www.jstor.org/stable/20864244

Leverence, M. E. Q. (1996). Utilizing the technical services staff on a public service desk. Technical Services Quarterly, 13(2), 1-13. https://doi.org/10.1300/J124v13n02_01

Lewis, C. (2018). Academic Librarian Status. Retrieved from https://academiclibrarianstatus.wordpress.com/\#status05

Linares, R. H., \& Johnson, A. M. (2016). Comparing apples to apples oranges: An exploration of the use of LibGuides in ARL libraries. The Southeastern Librarian, 64(1), 16. https://digitalcommons.kennesaw.edu/seln/vol64/iss1/16

McCallum, C. J., \& Collins, B. L. (2011). Enhancing the information literacy classroom experience: A cataloger and a reference librarian team up to deliver library instruction. Library Collections, Acquisitions, and Technical services, 35(1), 10-18. https://doi.org/10.1080/14649055.2011.10766287

Miller, M. M., \& Horan, M. (2017). Evolving roles of preservation professionals: Trends in position announcements from 2004 to 2015. Library Resources \& Technical Services, 61(4), 183. https://doi.org/10.5860/lrts.61n4.183

Mlinar, C. (2014). Cataloging as a Public Service? I Think So! Retrieved from https://libprofdev.wordpress.com/2014/01/03/cataloging-as-a-public-service-i-think-so/

Patel, S. (2016). Collection development in academic libraries. International Journal of Library and Information Science, 8(7), 62-67. https://academicjournals.org/journal/IJLIS/articlefull-text-pdf/FC733EB61220

Rech, D., \& Mortimore, J. (2020). From soup to nuts: Expanding liaison and technical services for OER development. International Journal of Open Educational Resources, 2 (1). https://www.ijoer.org/from-soup-to-nuts-expanding-liaison-and-technical-services-foroer-development-doi10-18278-ijoer-2-1-12

Reeb, B., \& Gibbons, S. (2004). Students, librarians, and subject guides: Improving a poor rate of return. portal: Libraries and the Academy, 4(1), 123-130. doi: 10.1353/pla.2004.0020

Reitz, J. M. (2014). Online Dictionary for Library and Information Science. ABC-CLIO. https://products.abc-clio.com/ODLIS/odlis_t.aspx

Smith, M. M. (2008). 21st century readers' aids: Past history and future directions. Journal of Web Librarianship, 2(4), 511-523. https://doi.org/10.1080/19322900802473886

Springshare. (2020). About. https://www.springshare.com/about.html 
This is a preprint of an article whose final and definitive form was published in Technical Services Quarterly 38(3), 236-257. Print ISSN: 0731-7131 Online ISSN: 1555-3337. Online published on May 16, 2021. The final authenticated version is available at: https://doi.org/10.1007/s11192-021-040186. Copyright 2021. Taylor \& Francis.

American Library Association. (2021). Technical Services Librarians. http://www.ala.org/educationcareers/libcareers/jobs/technical

Turner, L. \& Nann, A. (2013). Venturing from the "Back Room": Do technical services librarians have a role in information literacy? In B. R. Bernhardt, L. H. Hinds, \& K. P. Strauch (Eds.), Too Much is Not Enough: Charleston Conference Proceedings (pp. 392397) Purdue University Press. https://www.jstor.org/stable/j.ctt6wq772.71 
This is a preprint of an article whose final and definitive form was published in Technical Services Quarterly 38(3), 236-257. Print ISSN: 0731-7131 Online ISSN: 1555-3337. Online published on May 16, 2021. The final authenticated version is available at: https://doi.org/10.1007/s11192-021-040186. Copyright 2021. Taylor \& Francis.

Appendix A. List of colleges and universities that treat librarians as faculty

1. Adelphi University

2. Appalachian State University

3. Ashland University

4. Auburn University

5. Augusta State University

6. Austin Peay State University

7. Baptist Bible College

8. Baton Rouge Community College

9. Bergen Community College

10. Binghamton University

11. Bloomsburg University

12. Boise State University

13. California Polytechnic State University

14. California University

15. Capilano University

16. Carnegie Mellon University

17. Clarion University

18. Clemson University

19. College of New Jersey

20. Colorado School of Mines

21. Community College of Philadelphia

22. California State University

1) Bakersfield

2) Cal Maritime

3) Cal Poly Pomona

4) Cal Poly San Luis

5) Chico

6) Dominguez Hills

7) East Bay

8) Fresno

9) Fullerton

10) Humboldt

11) Los Angles

12) Long Beach

13) Monterey

14) Northridge

15) Sacramento 
This is a preprint of an article whose final and definitive form was published in Technical Services Quarterly 38(3), 236-257. Print ISSN: 0731-7131 Online ISSN: 1555-3337. Online published on May 16, 2021. The final authenticated version is available at: https://doi.org/10.1007/s11192-021-040186. Copyright 2021. Taylor \& Francis.

16) San Bernardino

17) San Diago

18) San Francisco

19) San Jose

20) San Marcos

21) Sonoma

22) Stanislaus

23. City University of New York (CUNY)

1) Baruch College

2) Borough of Manhattan Community College

3) Bronx of Community College

4) Brooklyn College

5) City College of New York

6) Craig Newmark Graduate School of Journalism at CUNY

7) CUNY Graduate Center

8) CUNY School of Law

9) Guttman Community College

10) Hostos Community College

11) Hunter College

12) John Jay College of Criminal Justice

13) Kingsborough Community College

14) LaGuardia Community College

15) Lehman College

16) Medgar Evers College

17) New York College of Technology

18) Queens College

19) Queensborough Community College

20) York College

24. Dominican University

25. Drew University

26. East Carolina University

27. East Stroudsburg University

28. Eastern Michigan University

29. Elmhurst College

30. Elon University

31. Ferris State University

32. Florida International University

33. Florida Southern College 
This is a preprint of an article whose final and definitive form was published in Technical Services Quarterly 38(3), 236-257. Print ISSN: 0731-7131 Online ISSN: 1555-3337. Online published on May 16, 2021. The final authenticated version is available at: https://doi.org/10.1007/s11192-021-040186. Copyright 2021. Taylor \& Francis.

34. Fort Lewis College

35. Fresno Pacific University

36. Furman University

37. George Mason University

38. Georgia Institute of Technology

39. Georgia Southern University

40. Georgia State University

41. Gonzaga University

42. Grand Valley State University

43. Gustavus Adolphus College

44. Hobart and William Smith College

45. Hofstra University, Hempstead

46. Humboldt State University

47. Huntingdon College, Montgomery

48. Idaho State University

49. Illinois State University

50. Illinois Wesleyan University

51. Indiana State University

52. Indiana University

1) Bloomington

2) Indianapolis

3) Kokomo

53. Indiana University of Pennsylvania

54. James Madison University

55. John Carroll University

56. Kent State University

57. Kutztown University

58. Lamar University

59. Lewis-Clark State College

60. Lincoln University

61. Lock Haven University

62. Long Island University

63. Longwood University

64. Los Angeles Harbor College

65. Louisiana State University

66. Loyola University Chicago

67. Loyola University New Orleans

68. Luther College 
This is a preprint of an article whose final and definitive form was published in Technical Services Quarterly 38(3), 236-257. Print ISSN: 0731-7131 Online ISSN: 1555-3337. Online published on May 16, 2021. The final authenticated version is available at: https://doi.org/10.1007/s11192-021-040186. Copyright 2021. Taylor \& Francis.

69. Lycoming College

70. Mansfield University

71. Maricopa County Community College District

72. Marshall University

73. Marymount University

74. McGill University (Canada)

75. Miami Dade College

76. Michigan State University

77. Middle Tennessee State University

78. Millersville University

79. Millikin University, Decatur

80. Minnesota State University

1) Mankato

2) Morehead

81. Mississippi State University

82. Montana State University

83. Montclair State University

84. Moorpark College

85. Murray State University

86. New Mexico State University

87. New York University

88. Northern Kentucky University

89. Northern Michigan University

90. Oakland University

91. Ohio Northern University

92. Ohio State University

1) Main campus

2) Lima

93. Oklahoma State University

94. Old Dominion University

95. Oregon State University

96. Our Lady of the Lake University of San Antonio

97. Oxnard College

98. Portland State University

99. Radford University

100. Ramapo College of New Jersey

101. Rider University

102. Ringling College of Art + Design 
This is a preprint of an article whose final and definitive form was published in Technical Services Quarterly 38(3), 236-257. Print ISSN: 0731-7131 Online ISSN: 1555-3337. Online published on May 16, 2021. The final authenticated version is available at: https://doi.org/10.1007/s11192-021-040186. Copyright 2021. Taylor \& Francis.

103. Sam Houston State University

104. San Diego State University

105. San Francisco State University

106. San Jose State University

107. Shippensburg University

108. Slippery Rock University

109. Sonoma State University

110. Southeast Missouri State University

111. Southern Connecticut State University

112. Southern Illinois University Edwardsville

113. Southern Oregon University

114. Southern Utah University

115. Southwestern Oklahoma State University

116. St. Cloud State University

117. St. Louis University

118. State University of New York

119. Stephen F. Austin State University

120. Stetson University

121. Stony Brook University

122. Texas A\&M University-Corpus Christi

123. Texas Tech University

124. The Catholic University of America

125. The Citadel

126. The Medical University of South Carolina

127. The Pennsylvania State University

128. Tidewater Community College

129. Trinity University

130. University of Alabama at Tuscaloosa

131. University of Albany

132. University of Arizona

133. University of Arkansas

1) Little Rock

2) Fayetteville

134. University of Central Arkansas

135. University of Central Florida

136. University of Charleston

137. University of Cincinnati

138. University of Dayton 
This is a preprint of an article whose final and definitive form was published in Technical Services Quarterly 38(3), 236-257. Print ISSN: 0731-7131 Online ISSN: 1555-3337. Online published on May 16, 2021. The final authenticated version is available at: https://doi.org/10.1007/s11192-021-040186. Copyright 2021. Taylor \& Francis.

139. University of Denver

140. University of Georgia

141. University of Hawaii

142. University of Idaho

143. University of Illinois

144. University of Kentucky

145. University of Louisville

146. University of Maryland

1) Baltimore County

2) College Park

147. University of Massachusetts

1) Amherst

2) Boston

3) Dartmouth

4) Lowell

148. University of Memphis

149. University of Miami

150. University of Michigan

151. University of Mississippi

152. University of Montana

153. University of Montevallo

154. University of Nebraska

1) Kearney

2) Lincoln

3) Omaha

155. University of Nevada

1) Las Vegas

2) Reno

156. University of New Hampshire

157. University of New Mexico

158. University of North Carolina

159. University of North Carolina

160. University of North Texas

161. University of Northern Colorado

162. University of Northern Iowa

163. University of Notre Dame

164. University of Rhode Island

165. University of Richmond 
This is a preprint of an article whose final and definitive form was published in Technical Services Quarterly 38(3), 236-257. Print ISSN: 0731-7131 Online ISSN: 1555-3337. Online published on May 16, 2021. The final authenticated version is available at: https://doi.org/10.1007/s11192-021-040186. Copyright 2021. Taylor \& Francis.

166. University of Saskatchewan (Canada)

167. University of Scranton

168. University of South Alabama

169. University of South Carolina

170. University of South Florida

1) Main

2) St. Petersburg

171. University of Southern California

172. University of Southern Mississippi

173. University of Tennessee

174. University of Toledo

175. University of Utah

176. University of West Georgia

177. University of Wisconsin

1) La Crosse

2) Stevens Point

178. Valdosta State University

179. Valparaiso University

180. Ventura County Community College District

181. Virginia Commonwealth University

182. Walsh University, North Canton

183. Washington College of Law

184. Washington State University

185. Weill Cornell Medical College of Cornell University

186. West Chester University, West Chester

187. West Virginia University

188. Western Carolina University

189. Western Illinois University

190. Western Michigan University

191. Western Washington University

192. William Paterson University

This list contains 192 college and universities with a total number of 246 libraries. 
This is a preprint of an article whose final and definitive form was published in Technical Services Quarterly 38(3), 236-257. Print ISSN: 0731-7131 Online ISSN: 1555-3337. Online published on May 16, 2021. The final authenticated version is available at: https://doi.org/10.1007/s11192-021-040186. Copyright 2021. Taylor \& Francis.

Appendix B. List of colleges and universities that consider librarians as faculty

1. Arizona State University

2. Aurora University

3. Beloit College

4. Bridgewater State College

5. Cornell University

6. Dickinson College

7. Duke University

8. Emory University

9. Gallaudet University

10. Harvard University

11. John Hopkins

12. Massachusetts Institute of Technology Libraries

13. New Jersey Institute of Technology

14. North Dakota State University

15. Princeton University

16. Sewanee: The University of the South

17. Stanford University

18. Temple University

19. Texas Christian University

20. The George Washington University

21. Tulane University

22. University of Califonia

1) Burkley

2) Davis

3) Irvine

4) Merced

5) Riverside

6) San Diago

7) San Francisco

8) Santa Barbara

9) Santa Cruz

10) UCLA

23. University of Connecticut

24. University of Iowa

25. University of Manitoba

26. University of Massachusetts, Worcester

27. University of Minnesota, Twin Cities 
This is a preprint of an article whose final and definitive form was published in Technical Services Quarterly 38(3), 236-257. Print ISSN: 0731-7131 Online ISSN: 1555-3337. Online published on May 16, 2021. The final authenticated version is available at: https://doi.org/10.1007/s11192-021-040186. Copyright 2021. Taylor \& Francis.

28. University of Missouri, Columbia

29. University of North Carolina, Chapel Hill

30. University of Pennsylvania

31. University of Texas

32. University of Tulsa

33. University of Washington

34. University of Wisconsin, Madison

35. Vanderbilt University

36. Wayne State University

37. Wellesley College

38. West Texas A\&M University

39. Western State College of Colorado

40. Wilkes University

41. Yale University

This list contains 41 colleges and universities with a total number of 50 libraries. 
This is a preprint of an article whose final and definitive form was published in Technical Services Quarterly 38(3), 236-257. Print ISSN: 07317131 Online ISSN: 1555-3337. Online published on May 16, 2021. The final authenticated version is available at: https://doi.org/10.1007/s11192-021-04018-6. Copyright 2021. Taylor \& Francis.

Table 1. Overview of Library Guides and Libraries

\begin{tabular}{|c|c|c|c|c|c|c|c|}
\hline & $\begin{array}{c}\text { Total } \\
\text { Number of } \\
\text { College \& } \\
\text { Universities }\end{array}$ & $\begin{array}{c}\text { Total } \\
\text { Number of } \\
\text { Libraries }\end{array}$ & $\begin{array}{c}\text { Total } \\
\text { Number of } \\
\text { Library } \\
\text { Guides }\end{array}$ & Lowest & Highest & $\begin{array}{c}\text { Average } \\
\text { per Library }\end{array}$ & $\begin{array}{c}\text { Total } \\
\text { Number by } \\
\text { Technical } \\
\text { Services }\end{array}$ \\
\hline $\begin{array}{l}\text { Libraries } \\
\text { (Faculty) }\end{array}$ & 192 & 246 & 47,602 & 3 & 1496 & 193.50 & 2,716 \\
\hline $\begin{array}{l}\text { Libraries } \\
\text { (Professional) }\end{array}$ & 41 & 50 & 16,265 & 29 & 930 & 325.3 & 1,240 \\
\hline
\end{tabular}

Table 2. Library Guides by Technical Services Librarians in the Libraries (Faculty)

\begin{tabular}{|c|c|c|c|c|c|c|c|c|}
\hline & Acquisition & $\begin{array}{c}\text { Cataloging } \\
\& \\
\text { Metadata }\end{array}$ & $\begin{array}{c}\text { Collection } \\
\text { Development }\end{array}$ & $\begin{array}{l}\text { Continuing } \\
\text { \& Electronic } \\
\text { Resources }\end{array}$ & Preservation & $\begin{array}{c}\text { Technical } \\
\text { Services } \\
\text { (Solo) }\end{array}$ & $\begin{array}{l}\text { Technical } \\
\text { Services } \\
\text { (General) }\end{array}$ & $\begin{array}{c}\text { Percentage } \\
\text { of Overall } \\
\text { Total }\end{array}$ \\
\hline Subject Guides & 68 & 218 & 355 & 274 & 5 & 150 & $\mathbf{1 , 0 7 0}$ & $2.25 \%$ \\
\hline Course Guides & 34 & 132 & 300 & 154 & 0 & 26 & 646 & $1.36 \%$ \\
\hline Others & 57 & 159 & 350 & 331 & 2 & 101 & 1,000 & $2.10 \%$ \\
\hline Total & 159 & 509 & 1,005 & 759 & 7 & 277 & 2,716 & $5.71 \%$ \\
\hline $\begin{array}{l}\text { Percentage of } \\
\text { Overall Total }\end{array}$ & $0.33 \%$ & $1.07 \%$ & $2.11 \%$ & $1.59 \%$ & $0.01 \%$ & $0.58 \%$ & $5.71 \%$ & \\
\hline
\end{tabular}


This is a preprint of an article whose final and definitive form was published in Technical Services Quarterly 38(3), 236-257. Print ISSN: 07317131 Online ISSN: 1555-3337. Online published on May 16, 2021. The final authenticated version is available at:

https://doi.org/10.1007/s11192-021-04018-6. Copyright 2021. Taylor \& Francis.

Table 3. Library Guides by Technical Services Librarians in the Libraries (Professional)

\begin{tabular}{|c|c|c|c|c|c|c|c|c|}
\hline & Acquisition & $\begin{array}{c}\text { Cataloging } \\
\& \\
\text { Metadata }\end{array}$ & $\begin{array}{c}\text { Collection } \\
\text { Development }\end{array}$ & $\begin{array}{l}\text { Continuing } \\
\text { \& Electronic } \\
\text { Resources }\end{array}$ & Preservation & $\begin{array}{c}\text { Technical } \\
\text { Services } \\
\text { (in general) }\end{array}$ & $\begin{array}{c}\text { Technical } \\
\text { Services } \\
\text { (General) }\end{array}$ & $\begin{array}{c}\text { Percentage } \\
\text { of Overall } \\
\text { Total }\end{array}$ \\
\hline Subject Guides & 22 & 8 & 523 & 24 & 0 & 4 & 581 & $3.57 \%$ \\
\hline Course Guides & 15 & 9 & 272 & 3 & 0 & 0 & 299 & $1.84 \%$ \\
\hline Others & 15 & 17 & 271 & 52 & 0 & 5 & 360 & $2.21 \%$ \\
\hline Total & 52 & 34 & 1,066 & 79 & $\mathbf{0}$ & 9 & 1,240 & $7.62 \%$ \\
\hline $\begin{array}{l}\text { Percentage of } \\
\text { Overall Total }\end{array}$ & $0.32 \%$ & $0.21 \%$ & $6.55 \%$ & $0.49 \%$ & $0.00 \%$ & $0.06 \%$ & $7.62 \%$ & \\
\hline
\end{tabular}

Table 4. Z-test

\begin{tabular}{lccccccc}
\hline & Acquisition & $\begin{array}{c}\text { Cataloging } \\
\&\end{array}$ & $\begin{array}{c}\text { Collection } \\
\text { Detadata }\end{array}$ & $\begin{array}{c}\text { Continuing } \\
\text { \& Electronic } \\
\text { Resources }\end{array}$ & Preservation & $\begin{array}{c}\text { Technical } \\
\text { Services } \\
\text { (Solo) }\end{array}$ & $\begin{array}{c}\text { Technical } \\
\text { Services } \\
\text { (General) }\end{array}$ \\
\hline Z-score & $H_{1}$ & $H_{2}$ & $H_{3}$ & $H_{4}$ & $H_{5}$ & $H_{6}$ & $\boldsymbol{H}_{7}$ \\
P-value & 0.28 & 10.32 & -27.62 & 10.73 & $\mathrm{n} / \mathrm{a}$ & 8.68 & $-\mathbf{8 . 7 6}$ \\
\hline
\end{tabular}

